\title{
ANALISIS KEBIJAKAN TENTANG PENYELENGGARAAN SEKOLAH/MADRASAH BERTARAF INTERNASIONAL (SMBI)
}

\author{
Muhammad Walid \\ Dosen pada program studi PGMI UIN Malang
}

\begin{abstract}
This article tries to discuss policy of international school that is the government's efforts to improve the quality of Indonesian education for belonging competitiveness among an others countries in the global era. One of them adopts international standards of OECD members as a key factor in addition as well as uses national education standards. In practice, international school policy starts to look some weaknesses, both conceptual and learning system. Like proverb says 'there is no ivory that is not cracked', so the government should perform various steps to improve the concept of international school by involving the various elements of education stakeholders and conduct in-depth research before the policy is decided.

Key word: School, Madrasah, International
\end{abstract}

\section{A. Pendahuluan}

Salah satu permasalahan pendidikan yang dihadapi oleh bangsa Indonesia adalah rendahnya kualitas pendidikan pada setiap jenjang dan satuan pendidikan, khususnya pendidikan dasar dan menengah. Karena itu upaya membangun pendidikan yang berkualitas di Indonesia merupakan sebuah keharusan yang sangat mendesak untuk mengejar ketertinggalan dari pendidikan di negara-negara maju.

Saat ini, kondisi pendidikan di negara-negara maju telah demikian familiar dengan penggunaan teknologi, metode-metode terbaru dalam pembelajaran serta kelengkapan fasilitas belajar. Namun, pada saat yang sama, kondisi pembelajaran di Indonesia masih mempunyai banyak persoalan dan kendala yang mengakibatkan secara umum kualitas pendidikan Indonesia masih jauh tertinggal, jika dibandingkan dengan kualitas pendidikan di negara-negara maju dan bahkan dengan negaranegara di Asia Tenggara. 
Menurut pengamatan Tilaar, dewasa ini dunia pendidikan Indonesia mengalami empat krisis pokok, yaitu kualitas, relevansi atau efisiensi eksternal, elitisme, dan manajemen, dengan uraian sebagai berikut. Pertama, kualitas Pendidikan. Sungguhpun sulit untuk menentukan karakteristik atau ukuran yang digunakan untuk mengukur kualitas pendidikan, namun beberapa indikator dapat di gunakan sebagai ramburambu pemberi sinyal mengenai kekhawatiran tentang mutu atau kualitas pendidikan. Beberapa indikator yang penting itu ialah mutu guru yang masih rendah pada semua jenjang pendidikan, serta rasio antara guru dan murid merupakan yang terendah di ASEAN.

Kedua, relevansi pendidikan. Masalah relevansi pendidikan atau efisiensi eksternal suatu sistem pendidikan diukur antara lain dari keberhasilan sistem itu dalam memasok tenaga-tenaga terampil dalam jumlah yang memadai bagi kebutuhan sektor-sektor pembangunan. Apabila dilihat lulusan pendidikan di Indonesia, maka tampak gejala yang semakin menghawatirkan dengan semakin besarnya pengangguran lulusan sekolah menengah dan pendidikan tinggi. Malahan ada tendensi semakin tinggi pendidikan itu semakin besar kemungkinan untuk menganggur. Masalah tidak relevannya pendidikan bukan saja disebabkan oleh adanya kesenjangan antara "supply" sistem pendidikan dengan "demand" tenaga yang dibutuhkan oleh berbagai sektor ekonomi, tetapi juga karena isi kurikulum yang tidak sesuai dengan perkembangan ekonomi atau kemajuan Iptek.

Ketiga, elitisme. Maksud elitisme dalam pendidikan ialah kecenderungan penyelenggaraan pendidikan oleh pemerintah yang tidak menguntungkan kelompok masyarakat yang kecil atau yang justru mampu.

Keempat, manajemen pendidikan. Mau tidak mau, pendidikan telah menjadi suatu industri. Sebagai suatu industri pengembangan (sumber daya) manusia maka pendidikan itu harus dikelola secara profesional. Ketiadaan tenaga-tenaga manajer pendidikan profesional ini antara lain yang mengharuskan untuk mengadakan terobosan-terobosan guna membawa pendidikan itu sejalan dengan langkah-langkah pendidikan yang semakin cepat. Di samping itu peta permasalahan pendidikan sangat kompleks yang menyangkut bukan saja masalah-masalah teknis pendidikan, tetapi meliputi kegiatan-kegiatan perencanaan, pendanaan dan efisiensi dari sistem itu sendiri (Tilaar, 2001, 37). 
Era globalisasi yang sudah merambah ke dalam dunia pendidikan, menuntut lembaga-lembaga pendidikan, terutama dalam kaitan ini sekolah, untuk melakukan berbagai upaya yang berorientasi pada penciptaan kompetensi lulusan yang berdaya saing global. Sekolah dituntut untuk dapat mencetak kader-kader pembangunan yang mampu berkompetisi dan menjadi pemenang dalam persaingan global. Oleh karena itu, pembenahan pada proses penyelenggaraan pendidikan di sekolah agar sesuai dengan tuntutan global menjadi sebuah keharusan yang tak terelakkan. Sekolah berubah dari zaman ke zaman. Di masa depan sekolah akan berubah dari format kelas menjadi sekolah bersama dalam satu kota, sekolah bersama dalam satu negara, bahkan bersama di dunia atau sekolah global.

Sehubungan dengan hal tersebut, pemerintah melalui Departemen Pendidikan Nasional membuat program sekolah/madrasah bertaraf internasional yang disingkat dengan SMBI. Kebijakan ini merupakan pengejawantahan dari amanat Pasal 50 ayat (3) UU No. 20 Tahun 2003 tentang Sistem Pendidikan Nasional, yaitu: "Pemerintah dan/atau pemerintah daerah menyelenggarakan sekurang-kurangnya satu satuan pendidikan pada semua jenjang pendidikan untuk dikembangkan menjadi satuan pendidikan yang bertaraf internasional".

Kebijakan SMBI ini dimaksudkan untuk mengangkat daya saing SDM Indonesia pada aras global baik untuk tenaga kerja maupun akses ke pendidikan lebih lanjut pada perguruan tinggi terkemuka di dalam negeri maupun luar negeri. SMBI berbeda dengan sekolah internasional, karena SMBI menggunakan kurikulum nasional yang diadaptasi, sedangkan sekolah internasional mengadopsi kurikulum lain yang menjadi sekolah mitranya. SMBI juga berbeda dengan immersi, karena bukan hanya pengajarannya saja yang bilingual (Bahasa Indonesia dan Bahasa Inggris) tetapijuga kurikulumnya.

Permasalahannya sekarang adalah banyak sekali para pemerhati pendidikan, pengambil kebijakan, stakeholder, masyarakat belum memahami konsep SMBI, karakteristik, model penyelenggaraan SMBI, landasan hokum SMBI. Persoalan ini menjadi penting untuk dikaji, karena sekolah dalam konteks ini merupakan avant garde dalam implementasi kebijakan SMBI. Artinya, jika sekolah mampu memformulasikan implementasi kebijakan SMBI secara tepat maka tujuan dari kebijakan ini seperti yang telah dikemukakan di atas akan dapat diwujudkan dengan 
baik. Tetapi sebaliknya, jika sekolah gagal dalam memahami dan memformulasikan implementasinya dalam tataran operasional penyelenggaraan pendidikan di sekolah, maka kebijakan ini hanya sekedar political will pemerintah yang "tak bermakna apa-apa".

\section{B. Realitas di lapangan}

1. Kebijakan Sekolah/Madrasah Bertaraf Internasional (SMBI)

a. Landasan Hukum

1) UU Sisdiknas Pasal 50 Ayat 3

Pemerintah dan/atau pemerintah daerah menyelenggarakan sekurangkurangnya satu satuan pendidikan pada semua jenjang pendidikan untuk dikembangkan menjadi satuan pendidikan yang bertaraf internasional (Anonim, 2006).

2) Kebijakan Pokok Pembangunan Pendidikan Nasional dalam Rencana Strategis Departemen Pendidikan Nasional Tahun 2005-2009.

a) Pemerataan dan Perluasan Akses

b) Peningkatan Mutu, Relevansi, dan Daya Saing. Salah satunya pembangunan sekolah bertaraf internasional untuk meningkatkan daya saing bangsa. Dalam hal ini, pemerintah perlu mengembangan SBI pada tingkat kabupaten/kota melalui kerja sama yang konsisten antara Pemerintah dengan Pemerintah Kabupaten/Kota yang bersangkutan untuk mengembangkan SD, SMP, SMA, dan SMK yang bertaraf internasional sebanyak 112 unit di seluruh Indonesia.

c) Penguatan Tata Kelola, Akuntabilitas, dan Pencitraan Publik (Anonim, 2006).

b. Konsep Sekolah Bertaraf Internasional (SBI)

1) Filosofi Eksistensialisme dan Esensialisme

Penyelenggaraan SBI didasari filosofi eksistensialisme dan esensialisme (fungsionalisme). Filosofi eksistensialisme berkeyakinan bahwa pendidikan harus menyuburkan dan mengembangkan eksistensi peserta didik seoptimal mungkin melalui fasilitas yang dilaksanakan melalui proses pendidikan yang bermartabat, pro-perubahan, kreatif, inovatif, dan eksperimentif), menumbuhkan dan mengembangkan bakat, minat, dan kemampuan peserta didik (Kir Haryana, 2007, 37). 
Filosofi eksistensialisme berpandangan bahwa dalam proses belajar mengajar, peserta didik harus diberi perlakuan secara maksimal untuk mengaktualkan, mengeksiskan, menyalurkan semua potensinya, baik potensi (kompetensi) intelektual (IQ), emosional (EQ), dan Spiritual (SQ).

Filosofi esensialisme menekankan bahwa pendidikan harus berfungsi dan relevan dengan kebutuhan, baik kebutuhan individu, keluarga, maupun kebutuhan berbagai sektor dan sub-sub sektornya, baik lokal, nasional, maupun internasional. Terkait dengan tuntutan globalisasi, pendidikan harus menyiapkan sumber daya manusia Indonesia yang mampu bersaing secara internasional. Dalam mengaktualkan kedua filosofi tersebut, empat pilar pendidikan, yaitu: learning to know, learning to do, learning to live together, and learning to be merupakan patokan berharga bagi penyelarasan praktek-praktek penyelenggaraan pendidikan di Indonesia, mulai dari kurikulum, guru, proses belajar mengajar, sarana dan prasarana, hingga sampai penilainya.

\section{2) $\mathrm{SNP}+\mathrm{X}(\mathrm{OECD})$}

Rumusan SNP + X (OECD) maksudnya adalah SNP singkatan dari Standar Nasional Pendidikan plus X. Sedangkan OECD singkatan dari Organization for Economic Co-operation and Development atau sebuah organisasi kerjasama antar negara dalam bidang ekonomi dan pengembangan. Anggota organisasi ini biasanya memiliki keunggulan tertentu dalam bidang pendidikan yang telah diakui standarnya secara internasional. Yang termasuk anggota OECD ialah: Australia, Austria, Belgium, Canada, Czech Republic, Denmark, Finland, France, Germany, Greece, Hungary, Iceland, Ireland, Italy, Japan, Korea, Luxembourg, Mexico, Netherlands, New Zealand, Norway, Poland, Portugal, Slovak Republic, Spain, Sweden, Switzerland, Turkey, United Kingdom, United States dan Negara maju lainnya seperti Chile, Estonia, Israel, Russia, Slovenia, Singapore, dan Hongkong.

Sebagaimana dalam "Pedoman Penjaminan Mutu Sekolah/Madrasah Bertaraf Internasional pada Jenjang Pendidikan Dasar dan Menengah tahun 2007", bahwa sekolah/madarasah internasional adalah yang sudah memenuhi seluruh Standar Nasioanl Pendidikan (SNP) dan diperkaya dengan mengacu pada standar pendidikan salah satu Negara anggota Organization for Economic Co-operation and Development (OECD) dan /atau Negara maju lainnya yang mempunyai keunggulan tertentu dalam bidang pendidikan, sehingga memiliki daya saing di forum Internasional. 
Jadi, SNP $+\mathrm{X}$ di atas artinya bahwa dalam penyelenggaraan SBI, sekolah/madrasah harus memenuhi Standar Nasional Pendidikan (Indonesia) dan ditambah dengan indikator X, maksudnya ditambah atau diperkaya/dikembangkan/diperluas/ diperdalam dengan standar anggota OECD di atas atau dengan pusat-pusat pelatihan, industri, lembaga-lembaga tes/sertifikasi inter-nasional, seperti Cambridge, IB, TOEFL/TOEIC, ISO, pusat-pusat studi dan organisasi-organisasi multilateral seperti UNESCO, UNICEF, SEAMEO, dan sebagainya.

Ada dua cara yang dapat dilakukan sekolah/madrasah untuk memenuhi karakteristik (konsep) Sekolah Bertaraf Internasional (SBI), yaitu sekolah yang telah melaksanakan dan memenuhi delapan unsur SNP sebagai indikator kinerja minimal ditambah dengan $(X)$ sebagai indikator kinerja kunci tambahan. Dua cara itu adalah: (1) adaptasi, yaitu penyesuaian unsur-unsur tertentu yang sudah ada dalam SNP dengan mengacu (setara/sama) dengan standar pendidikan salah satu anggota OECD dan/atau negara maju lainnya yang mempunyai keunggulan tertentu dalam bidang pendidikan, diyakini telah memiliki reputasi mutu yang diakui secara internasional, serta lulusannya memiliki kemampuan daya saing internasional; dan (2) adopsi, yaitu penambahan atau pengayaan/pendalaman/penguatan/perluasan dari unsur-unsur tertentu yang belum ada diantara delapan unsure SNP dengan tetap mengacu pada standar pendidikan salah satu anggota $\mathrm{OECD/negara} \mathrm{maju} \mathrm{lainnya} \mathrm{(Kir}$ Haryana, 2007, 41)

3) Model Penyelenggaraan SMBI

Terdapat dua model penyelenggaraan SBI yang dikembangkan di Indonesia, yaitu: (1) Model sekolah baru (Newly Developed); (2) Model Pengembangan Sekolah yang ada (Existing Developed).

\section{a. Sekolah Baru (Newly Developed).}

Dalam model ini, SBI didirikan dengan kondisi yang baru sama sekali dengan segala isinya. Model ini dipilih dengan asumsi bahwa untuk menjadikan sekolah bertaraf internasional harus memiliki karakteristik yang bertaraf internasional, mulai dari siswa, kurikulum, guru, kepala sekolah, sarana dan prasarana, dan sebagainya. Model ini sangat ideal karena dapat memenuhi keseluruhan persyaratan yang bertaraf internasional. Sistem penerimaan siswa baru dapat dilakukan dengan cara: (a) menerima siswa baru kelas 1, (b) memindahkan siswa dari sekolah lain. 
Dalam mencapai standar internasional sekolah baru tersebut perlu memprogramkan koalisi atau kemitraan dengan sekolah sejenis/sederajat di luar negeri.

\section{b. Pengembangan Sekolah yang sudah ada (Existing Developed).}

Pengembangan SBI dapat dilakukan dengan mengembangkan sekolah yang telah ada, khususnya sekolah dasar yang telah memenuhi seluruh standar nasional. Selain itu sekolah memiliki guru, kepala sekolah, tenaga kependidikan yang profesional dan tangguh, serta sarana prasarana yang memungkinkan dapat dikembangkan lebih lanjut.

Dalam mengembangkan SBI dari sekolah yang sudah ada, perlu diterapkan langkah-langkah perencanaan sebagai berikut: kondisi sekolah saat ini (existing condition), kondisi sekolah yang diharapkan (expected condition), strategi/tahapan pencapaian, dan bagaimana cara pencapaiannya. Dengan membandingkan kondisi saat ini dengan kondisi ideal saat menjadi SBI akan diketahui kesenjangan yang ada, baik fasilitas, guru, manajemen, kultur sekolah dan sebagainya. Kesenjangan itulah yang harus dikurangi dan didekatkan melalui strategi dan pentahapan yang jelas.

4) Karakteristik Sekolah/Madrasah Bertaraf Internasional

a). Karakteristik visi

Visi Sekolah Bertaraf Internasional adalah: Terwujudnya Insan Indonesia yang cerdas dan kompetitif secara internasional. Visi ini mengisyaratkan secara tidak langsung gambaran tujuan pendidikan yang diselenggarakan oleh sekolah model SBI, yaitu mewujudkan insan Indonesia yang cerdas dan kompetitif/memiliki daya saing secara internasional.

b). Karakteristik Esensial

Karakteristik esensial dalam indikator kunci minimal (SNP) dan indikator kunci tambahan (x) sebagai jaminan mutu pendidikan bertaraf internasional dapat dilihat pada table di bawah ini. 


\begin{tabular}{|c|c|c|c|}
\hline No & $\begin{array}{l}\text { Obyek } \\
\text { Penjaminan } \\
\text { Mutu (unsur } \\
\text { Pendidikan } \\
\text { dalam SNP) }\end{array}$ & $\begin{array}{l}\text { Indikator } \\
\text { Kinerja Kunci } \\
\text { Minimal } \\
\text { (dalam SNP) }\end{array}$ & $\begin{array}{ll}\text { Indikator } & \text { Kinerja } \\
\text { Tambahan sebagai (x-nya) }\end{array}$ \\
\hline I & Akreditasi & $\begin{array}{l}\text { Berakreditasi } \\
\text { A dari BAN- } \\
\text { Sekolah dan } \\
\text { Madrasah }\end{array}$ & $\begin{array}{l}\text { Berakreditasi tambahan dari } \\
\text { badan akreditasi sekolah pada } \\
\text { salah satu lembaga akreditasi } \\
\text { pada salah satu negara anggota } \\
\text { OECD dan/atau negara maju } \\
\text { lainnya yang mempunyai keung- } \\
\text { gulan tertentu dalam bidang } \\
\text { pendidikan }\end{array}$ \\
\hline \multirow[t]{4}{*}{ II } & \multirow[t]{4}{*}{$\begin{array}{l}\text { Kurikulum } \\
\text { (Standar Isi) } \\
\text { dan Standar } \\
\text { Kompe-tensi } \\
\text { lulusan }\end{array}$} & $\begin{array}{l}\text { Menerapkan } \\
\text { KTSP }\end{array}$ & $\begin{array}{l}\text { Sekolah telah menerapkan } \\
\text { system administrasi akademik } \\
\text { berbasis teknologi Informasi dan } \\
\text { Komu-nikasi (TIK) dimana setiap } \\
\text { siswa dapat meng-akses } \\
\text { transkipnya masing-masing. }\end{array}$ \\
\hline & & $\begin{array}{l}\text { Memenuhi } \\
\text { Standar Isi }\end{array}$ & $\begin{array}{l}\text { Muatan pelajaramn (isis) dalam } \\
\text { kurikulum telah setara atau lebih } \\
\text { tinggi dari muatan pelajaran } \\
\text { yang sama pada sekolah unggul } \\
\text { dari salah satu negara diantara } \\
30 \text { negara anggota OECD } \\
\text { dan/atau dari negara maju } \\
\text { lainnya. }\end{array}$ \\
\hline & & $\begin{array}{l}\text { Memenuhi } \\
\text { SKL }\end{array}$ & $\begin{array}{l}\text { Penerapan standar kelulusan } \\
\text { yang setara atau lebih tinggi dari } \\
\text { SNP }\end{array}$ \\
\hline & & & $\begin{array}{l}\text { Meraih mendali tingkat } \\
\text { internasional pada berbagai } \\
\text { kompetensi sains, matematika, } \\
\text { tekno-logi, seni, dan olah raga. }\end{array}$ \\
\hline III & Proses Pembel. & $\begin{array}{l}\text { Memenuhi } \\
\text { Standar } \\
\text { Proses }\end{array}$ & $\begin{array}{l}\text { - Proses pembelajaran pada } \\
\text { semua mata pelajaran telah } \\
\text { menjadi teladan atau rujukan } \\
\text { bagi sekolah lainnya dalam } \\
\text { pengembangan akhlak mulia, } \\
\text { budi pekerti luhur, kepribadian } \\
\text { unggul, kepemimpinan, jiwa }\end{array}$ \\
\hline
\end{tabular}




\begin{tabular}{|c|c|c|c|}
\hline & & & $\begin{array}{l}\text { kewirausahaan, jiwa patriot, } \\
\text { dan jiwa innovator } \\
\text { - Proses pembelajaran telah } \\
\text { diperkaya dengan model-model } \\
\text { proses pembelajaran sekolah } \\
\text { unggul dari salah satu negara } \\
\text { diantara } 30 \text { negara anggota } \\
\text { OECD dan/atau negara maju } \\
\text { lainnya. } \\
\text { - Penerapan proses pembelajaran } \\
\text { berbasis TIK pada semua mapel } \\
\text { - Pembelajaran pada mapel IPA, } \\
\text { Matematika, dan lainnya } \\
\text { dengan bahasa Inggris, kecuali } \\
\text { mapel bahasa Indonesia. }\end{array}$ \\
\hline IV & Penilaian & $\begin{array}{l}\text { Memenuhi } \\
\text { Standar } \\
\text { Penilai-an }\end{array}$ & $\begin{array}{l}\text { Sistem/model penilaian telah } \\
\text { diperkaya dengan system/model } \\
\text { penilaian dari sekolah unggul di } \\
\text { salah satu negara diantara } 30 \\
\text { negara anggota OECD dan/atau } \\
\text { negara maju lainnnya. }\end{array}$ \\
\hline $\mathrm{V}$ & Pendidik & $\begin{array}{l}\text { Memenuhi } \\
\text { Standar Pen- } \\
\text { didik }\end{array}$ & $\begin{array}{l}\text { - Guru sains, matematika, dan } \\
\text { teknologi mampu mengajar } \\
\text { dengan bahasa Inggris } \\
\text { - Semua guru mampu } \\
\text { memfasilitasi pembelajaran } \\
\text { berbasis TIK } \\
\text { - Minimal } 20 \% \\
\text { berpendidikan S2/S3 guru dari } \\
\text { perguruan tinggi yang program } \\
\text { studinya terakreditasi A } \\
\end{array}$ \\
\hline VI & $\begin{array}{l}\text { Tenaga } \\
\text { Kependidikan }\end{array}$ & $\begin{array}{l}\text { Memenuhi } \\
\text { Standar } \\
\text { Tenaga } \\
\text { Kependdkan }\end{array}$ & $\begin{array}{l}\text { - Kepala sekolah berpendidikan } \\
\text { minimal S2 dari perguruan } \\
\text { tinggi yang program studinya } \\
\text { terakreditasi A } \\
\text { - Kepala sekolah telah } \\
\text { menempuh pelatihan kepala } \\
\text { sekolah yang diakui oleh } \\
\text { Pemerintah } \\
\text { - Kepala sekolah mampu } \\
\text { berbahasa Inggris secara aktif } \\
\text {-Kepala sekolah memiliki visi }\end{array}$ \\
\hline
\end{tabular}




\begin{tabular}{|c|c|c|c|}
\hline & & & $\begin{array}{l}\text { internasional, mampu mem } \\
\text { bangun jejaring internasional, } \\
\text { memiliki } \\
\text { manajerial, serta jiwa ke } \\
\text { pemimpinan dan enterprenual } \\
\text { yang kuat }\end{array}$ \\
\hline$\overline{\text { VII }}$ & $\begin{array}{l}\text { Sarana } \\
\text { Prasarana }\end{array}$ & $\begin{array}{l}\text { Memenuhi } \\
\text { Standar } \\
\text { Sarana } \\
\text { Prasarana }\end{array}$ & $\begin{array}{l}\text {-Setiap ruang kelas dilengkapi } \\
\text { sarana pembel.berbasis TIK } \\
\text {-Sarana perpustakaan TELAH } \\
\text { dilengkapi dengan sarana } \\
\text { digital yang memberikan akses } \\
\text { ke sumber pembelajaran } \\
\text { berbasis TIK di seluruh dunia } \\
\text { - Dilengkapi dengan ruang multi } \\
\text { media, ruang unjuk seni } \\
\text { budaya, fasilitas olah raga, } \\
\text { klinik, dan lain-lain. }\end{array}$ \\
\hline $\begin{array}{l}\text { VII } \\
\text { I }\end{array}$ & Pengelolaan & $\begin{array}{l}\text { Memenuhi } \\
\text { Standar } \\
\text { Penge-lolaan }\end{array}$ & $\begin{array}{l}\text {-Sekolah meraih sertifikat ISO } \\
9001 \text { versi } 2000 \text { atau } \\
\text { sesudahnya (2001, dst) dan ISO } \\
14000 \\
\text { - Merupakan sekolah multi } \\
\text { kultural } \\
\text {-Sekolah telah menjalin } \\
\text { hubungan "sister school" } \\
\text { dengan } \\
\text { bertaraf/berstandar } \\
\text { internasional diluar negeri } \\
\text { - Sekolah terbebas dari rokok, } \\
\text { narkoba, kekerasan, kriminal, } \\
\text { pelecehan seksual, dan lain-lain } \\
\text {-Sekolah menerapkan prinsip } \\
\text { kesetaraan gender dalam semua } \\
\text { aspek pengelolaan sekolah }\end{array}$ \\
\hline IX & Pembiayaan & $\begin{array}{l}\text { Memenuhi } \\
\text { Standar Pem- } \\
\text { biayaan }\end{array}$ & $\begin{array}{llr}\text { - Menerapkan model } & \text { pem } \\
\text { biayaan yang efisien } & \text { untuk } \\
\text { mencapai berbagai } & \text { target } \\
\text { indikator kunci tambahan } & \\
\end{array}$ \\
\hline
\end{tabular}


c). Karakteristik Penjaminan Mutu (Quality Assurance)

(1). Output (produk)/lulusan SMBI

Adalah memiliki kemampuan-kemampuan bertaraf nasional plus internasional sekaligus, yang ditunjukkan oleh penguasaan SNP Indonesia dan penguasaan kemampuan-kemampuan kunci yang diperlukan dalam era global.

Ciri-ciri output/outcomes SBI sebagai berikut; (1) lulusan SBI dapat melanjutkan pendidikan pada satuan pendidikan yang bertaraf internasional, baik di dalam negeri maupun luar negeri, (2) lulusan SBI dapat bekerja pada lembaga-lembaga internasional dan/atau negaranegara lain, dan (3) meraih mendali tingkat internasional pada berbagai kompetensi sains, matematika, teknologi, seni, dan olah raga.

(2). Proses pembelajaran SBI

Ciri-ciri proses pembelajaran, penilaian, dan penyelenggaraan SBI sebagai berikut: (1) pro-perubahan, yaitu proses pembelajaran yang mampu menumbuhkan dan mengembangkan daya kreasi, inovasi, nalar, dan eksperimentasi untuk menemukan kemungkinan-kemungkinan baru, a joy of discovery, (2) menerapkan model pem-belajaran aktif, kreatif, efektif, dan menyenangkan; student centered; reflective learning, active learning; enjoyable dan joyful learning, cooperative learning; quantum learning; learning revolution; dan contextual learning, yang kesemuanya itu telah memiliki standar internasional; (3) menerapkan proses pembelajaran berbasis TIK pada semua mata pelajaran; (4) proses pembelajaran menggunakan bahasa Inggris, khususnya mata pelajaran sains, matematika, dan teknologi; (5) proses penilaian dengan menggunakan model penilaian sekolah unggul dari negara anggota OECD dan/atau negara maju lainnya, dan (6)dalam penyelenggaraan SBI harus menggunakan standar manajemen intenasional, yaitu mengoimplementasikan dan meraih ISO 9001 versi 2000 atau sesudahnya dan ISO 14000, dan menjalin hubungan sister school dengan sekolah bertaraf internasional di luar negeri.

(3). Input

Ciri input SBI ialah (1) telah terakreditasi dari badan akreditasi sekolah di salah negara anggota OECD atau negara maju lainnya, (2) standar lulusan lebih tinggi daripada standar kelulusan nasional, (3) jumlah guru minimal $20 \%$ berpendidikan S2/S3 dari perguruan tinggi 
yang program studinya terakreditasi A dan mampu berbahasa inggris aktif. Kepala sekolah minimal S2 dari perguruan tinggi yang program studinya terakreditasi A dan mampu berbahasa inggris aktif. (4) siswa baru (intake) diseleksi secara ketat melalui saringan rapor SD, ujian akhir sekolah, scholastic aptitude test (SAT), kesehatan fisik, dan tes wawancara. Siswa baru SBI memeliki potensi kecerdasan unggul yang ditunjukkan oleh kecerdasan intelektual, emosional, dan spiritual, dan berbakat luar biasa.

\section{Analisis SWOT}

1. Kekuatan

Kebijakan pemerintah mengenai SMBI didukung secara konstitusi dalam UU No. 20 tahun 2003 tentang Sisdiknas Pasal 50 ayat (3). Karena kebijakan ini sudah ditetapkan dalam undang-undang secara otomatis telah mendapatkan dukungan yang kuat dari berbagai pihak, khususnya dari wakil rakyat yang menduduki kursi di DPR RI.

Di samping itu, SMBI merupakan proyek prestisius, karena akan dibiayai oleh Pemerintah Pusat 50\%, Pemerintah Propinsi 30\%, dan Pemerintah Kabupaten/Kota 20\%. Padahal, untuk setiap sekolahnya saja Pemerintah Pusat mengeluarkan 300 juta rupiah setiap tahun paling tidak selama 3 (tiga) tahun dalam masa rintisan tersebut.

Kekuatan lain adalah perkembangan yang signifikan tentang ditetapkannya anggaran pendidikan sebesar $20 \%$ dari APBN. Ketetapan ini merupakan dukungan yang tidak kalah pentingnya bagi perkembangan SMBI. Bagaimanapun juga proyek SMBI menyedot dana yang besar dan pemerintah harus mempriotaskannya sebelum penganggaran bidang lainnya.

Kebijakan penyelenggaraan SMBI juga ditunggu oleh banyak masyarakat yang prihatin dengan ketertinggalan mutu pendidikan di Indonesia, karena SMBI adalah sebuah kebijakan pemerintah Indonesia untuk memperbaiki kualitas pendidikan nasional agar memiliki daya saing dengan negara-negara maju lainnya. Oleh karenanya, kebijakan ini memiliki motivasi yang kuat tersendiri untuk mensejajarkan pendidikan Indonesia dengan negara-negara maju lainnya.

Kekuatan lainnya adalah kesadaran masyarakat Indonesia untuk melakukan perubahan setelah berakhirnya masa orde baru-memasuki masa reformasi, termasuk perubahan dalam bidang pendidikan. SMBI 
adalah salah satu upaya pemerintah untuk melakukan perubahanperubahan dalam bidang pendidikan menghadapi persaingan global.

2. Kelemahan

a. Sumber daya manusia belum sekarang ini belum siap. Para guru dan tenaga kependidikan sangat lemah dalam penguasaan bahasa Inggris (khususnya guru yang akan mengajar di SMBI). Padahal penguasaan bahasa Inggris adalah mutlak dikuasai para guru karena bahasa tersebut dipakai sebagai bahasa pengantara dan komunikasi sehari-hari. Di samping itu, penguasaan teknologi canggih para tenaga pendidik dan tenaga kependidikan masih sangat lemah. Padahal SMBI menggunakan fasilitas ICT canggih yang disesuaikan dengan standar internasional. Oleh karena itu, mau tidak mau SMBI menuntut keberadaan sumber daya yang canggih dan profesional.

b. Sarana prasarana yang akan dibangun/dimiliki sangat belum memadai. Baik Model sekolah baru atau model pengembangan sekolah yang telah ada tentunya menuntut biaya yang sangat mahal karena harus standar internasional, contohnya, SMBI harus menyediakan lahan seluas minimal $15.000 \mathrm{~m} 2$, belum lagi sarana prasarana lainnya yang serba internasional sebagaimana yang tertera dalam buku panduan. Di tengah-tengah krisis ekonomi yang melanda bangsa Indonesia dalam 10 tahun terakhir ini rasanya sulit untuk memenuhi standar tersebut.

c. SBI lebih cenderung menggunakan perencanaan pendidikan dengan Pendekatan Cost Effectivenes (efektivitas biaya). Pendekatan Cost Effectiveness adalah pendekatan yg menitikberatkan pemanfaatan biaya secermat mungkin untuk mendapatkan hasil pendidikan yang seoptimal mungkin, baik secara kuantitatif maupun kualitatif. Pendidikan ini hanya diadakan jika benar-benar memberikan keuntungan yang relatif pasti, baik bagi penyelenggara maupun peserta didik. Konsekwensi dari pendekatan ini adalah tidak semua anak dapat mengenyam pendidikan di SBI, sebab SBI lebih menekankan efektivitas pendidikan dalam mencapai hasil yang optimal baik secara kuantitas maupun kualitas, sehingga input pun diambil dari anak-anak yang memiliki kemampuan unggul, baik secara akademik, emosional, spiritual bahkan finansial. Hal ini memiliki potensi terjadi sistem pendidikan yang bersifat Diskriminatif dan ekssklusif. Penyelenggaraan SMBI akan melahirkan konsep pendidikan yang diskri-minatif (hanya diperuntukkan bagi siswa yang memiliki kemampuan/kecerdasan unggul) dan ekslusif (pendidikan bagi anak orang kaya). 
d. Kebijakan SMBI bertolak belakang dengan otonomi sekolah dan Manajemen Berbasis Sekolah (MBS). Bergulirnya otonomi sekolah melahirkan sistem Manajemen Berbasis Sekolah (MBS). Sebagaimana kita ketahui, MBS digunakan sebagai legitimasi untuk menentukan kebijakan sistem pembelajaran di sekolah. Sekolah memiliki kemerdekaan untuk menentukan kebijakan yang diambil, termasuk kemerdekaan guru dan siswa untuk menentukan sistem pembelajarannya. Sedangkan dalam SBI, sekolah masih dibelenggu dengan sistem pembelajaran dari negara lain.

e. Konsep SNP+X kurang jelas. Dalam kurikulum SBI ada rumus SNP+X. Artinya Standar Nasional Pendidikan ditambah atau diperkaya/dikembangkan/diperluas/diperdalam dengan standar internasional dari salah satu anggota OECD atau lembaga tes/sertifikasi internsional. Faktor $X$ dalam rumus di atas tidak memiliki arah dan tujuan yang jelas. Sebab, konsep ini tidak menjelaskan lembaga/negara tertentu yang harus diadaptasi/diadopsi standarnya, dan faktor apa saja yang harus ditambah/diperkaya/dikembangkan/diperluas/diperdalam? Apakah sistem pembelajaran bahasanya, teknologinya, ekonominya, dan lainlain.

f. Konsep SBI cenderung lebih menekankan pada alat daripada proses. Indikasi ini nampak ketika penyelenggaraan SBI lebih mementingkan alat/media pembelajaran yang canggih, bilingual sebagai medium of instruction, berstandar internasional, daripada proses penanaman nilai pada peserta didik. tuntutan pendidikan global jangan diartikan hanya mempersoalkan kedudukan pendidikan kita terhadap rangking kita dengan negara-negara lain, akan tetapi harus kita arahkan kepada perbaikan pendidikan kita demi eksistensi anak bangsa kita untuk hidup di alam percaturan global, dengan kreativitasnya, dengan EI-nya dan dengan AQ-nya, dan dengan pengetahuannya yang tidak lepas dari kenyataan hidup nyata mereka.

3. Peluang

a. Undangan OECD yang berlokasi di Prancis terhadap Indonesia merupakan peluang yang sangat besar terwujudnya SMBI. OECD adalah organisasi internasional untuk membantu pemerintahan Negaranegara anggotanya menghadapi tantangan globalisasi ekonomi. 
b. Telah tersusunnya standar Nasional Pendidikan akan mempermudah penyelenggaraan SMBI di Indonesia, karena pada dasarnya SMBI adalah sekolah/madrasah yang sudah memenuhi seluruh standar Nasional Pendidikan yaitu sekolah/madrasah yang sudah melaksanakan standar isi, standar proses, standar kompetensi lulusan, standar pendidik dan tenaga kependidikan, standar sarana dan prasarana, standar pengelolaan, standar pembiayaan, dan standar penilaian. Di samping itu, peluang SMBI didasarkan pada konsepsi bahwa SMBI merupakan sekolah/madrasah yang sudah memenuhi seluruh standar Nasional Pendidikan dan diperkaya dengan mengacu pada standar pendidikan salah satu Negara anggota Organization for Economic Co-operation and Development (OECD) dan atau Negara maju lainnya yang mempunyai keunggulan tertentu dalam bidang pendidikan sehingga memiliki daya saing di forum Internasional. Pada prinsipnya, SMBI memberikan jaminan mutu pendidikan dengan standar yang lebih tinggi dari Standar Nasional Pendidikan.

c. Dukungan masyarakat akan bertambah banyak karena lulusan SMBI memiliki peluang antara lain dapat: (1) melanjutkan pendidikan pada satuan pendidikan yang bertaraf internasional, baik di dalam maupun luar negeri, (2) mengikuti sertifikasi bertaraf internasional yang diselenggarakan oleh salah satu Negara OECD dan atau Negara maju lainnya yang mempunyai keunggulan tertentu dalam bidang pendidikan, (3) meraih medali tingkat internasional pada berbagai kompetisi sains, matematika, teknologi, seni, dan olah raga, dan (4) bekerja pada lembaga-lembaga internasional dan atau Negara-negara lain.

4. Tantangan

a. Tantangan terbesar adalah bagaimana mengalahkan kebodohan dengan meningkatkan mutu SDM melalui pendidikan. Bangsa Indonesia harus melakukan perbaikan dan perubahan pada sektor pendidikan.

b. Tantangan yang dihadapi bagi penyelenggara SMBI adalah mendesak pemerintah agar merealisasikan anggaran pendidikan $20 \%$ dari APBN dan mendahulukannya di banding anggaran bidang yang lain

c. Tantangan lainnya adalah memberikan pemahaman kepada semua masyarakat tentang perlunya SMBI dalam meningkatkan mutu pendidikan dan mengejar ketertinggalan pendidikan di Indonesia agar bisa sejajar dengan pendidikan di Negara maju lainnya. 
d. Tantangan berikutnya adalah meningkatkan kualitas sumber daya pendidikan (pendidik dan kependidikan) secara maksimal baik terkait dengan bahasa, teknologi, profesionalitas dan kemampuan-kemampuan lain yang dibutuhkan.

e. Mengembalikan kondisi perekonomian Indonesia agar dapat mendukung terlaksananya kebijakan SMBI, karena bagaimanapun juga penyelenggaraan SMBI membutuhkan bantuan baik dari pemerintah pusat maupun daerah. Hal ini hanya bisa dilaksanakan dengan kondisi ekonomi yang meningkat dan stabil.

f. Tantangan lain yang perlu diperhitungkan adalah munculnya komersialisasi pendidikan kepada para pelanggan jasa pendidikan, semisal masyarakat, siswa atau orang tua. Indikasi ini nampak ketika sekolah SMBI menarik puluhan juta kepada siswa baru yang ingin masuk sekolah SMBI. Hal ini dilakukan dengan dalih bahwa sekolah tersebut bertaraf internasional, dilengkapi dengan sistem pembelajaran yang mengacu pada negara anggota OECD, menggunakan teknologi informasi canggih, bilingual, dan lain-lain.

\section{Temuan-Temuan: Kondisi Obyektif}

Ada beberapa hal yang perlu dikritisi yang akan dan telah terjadi di lapangan. Pertama, program ini nampaknya tidak didahului dengan riset yang mendalam dan konsepnya lemah. Dengan menyatakan bahwa SMBI $=\mathrm{SNP}+\mathrm{X}$, maka sebenarnya konsep SMBI ini tidak memiliki bentuk dan arah yang jelas. Jika konsep ini secara jelas menyatakan mengadopsi atau mengadaptasi standar pendidikan internasional seperti Cambridge IGCSE umpamanya, maka akan lebih jelas ke mana arah dari program ini. Dengan memasukkan TOEFL/TOEIC, ISO dan UNESCO sebagai " $X$ " juga menunjukkan bahwa Dikdasmen juga tidak begitu paham dengan apa yang ia maksud dengan " $X$ " tersebut. Sekolah-sekolah yang mengadopsi atau berkiblat pada standar internasional seperti Cambridge atau International Baccalaureate (IB) adalah sekolah-sekolah yang memang dirancang untuk mempersiapkan siswa-siswa mereka agar dapat melanjutkan ke luar negeri.

Dengan sistem kurikulum tersebut siswa mereka memang dipersiapkan untuk dapat belajar di luar negeri. Mereka bahkan tidak perlu mengikuti Ujian Nasional karena mereka memang tidak berencana untuk meneruskan pendidikan mereka di universitas di Indonesia. Jika yang 
hendak dituju adalah peningkatan kualitas pembelajaran dan output pendidikan maka mengadopsi IB ataupun mengikutsertakan siswa dalam ujian Cambridge bukanlah jawabannya. Ujian Cambridge diperuntukkan bagi siswa yang ingin melanjutkan pendidikannya ke luar negeri. Meski demikian, nilai yang tinggi dalam ujian Cambridge juga bukan jaminan bahwa siswa dapat diterima di perguruan tinggi di luar negeri. Nilai ujian Cambridge hanya akan memudahkan siswa untuk dapat diterima di PT LN karena nilai ujian Cambridge diakui oleh beberapa negara.

Permasalahannya adalah berapa banyak dari siswa kita sebenarnya yang ingin melanjutkan pendidikannya ke luar negeri? Berapa persenkah dari lulusan sekolah publik kita yang benar-benar ingin dan mampu, baik secara finansial maupun intelektual, untuk melanjutkan studinya ke luar negeri? Bukankah ini suatu pengorbanan yang sangat sia-sia yang bakal menelantarkan siswa-siswa lain yang tidak akan melanjutkan pendidikannya ke luar negeri? Untuk apa kita mengerahkan seluruh energi dan kapasitas kita membawa siswa menuju ke sistem Cambridge, umpamanya, jika sebenarnya tujuan yang hendak dituju bukanlah kesana? Ini adalah contoh tujuan pendidikan yang sangat misleading. Jelas sekali bahwa tidak mungkin sekolah harus mengikuti dua kiblat, yaitu UNAS dan Cambridge umpamanya, karena akan sangat menyulitkan bagi sekolah maupun murid untuk mengikuti dua kiblat tersebut. Beberapa sekolah National Plus yang selama ini memang dirancang untuk mengikuti dua kiblat tersebut mengakui bahwa sangat sulit bagi mereka untuk mengikuti dua kiblat tersebut sekaligus.

Kedua, Dikdasmen membuat rumusan 4 model pembinaan SMBI tersebut yaitu : (1) Model Sekolah Baru (Newly Developed), (2) Model Pengembangan pada Sekolah yang Telah Ada (Existing School), (3) Model Terpadu, dan (4) Model Kemitraan. Padahal kalau dilihat sebenarnya hanya ada dua model yaitu Model (1) Model Sekolah Baru dan Model (2) Model Sekolah yang Telah Ada. Dua lainnya hanyalah teknis pelaksanaannya saja. Dari dua model tersebut Dikdasmen sebenarnya hanya melakukan satu model rintisan yaitu Model (2) Model Pengembangan pada Sekolah yang Telah Ada (existing School) dan tidak memiliki atau berusaha untuk membuat model (1) Model Sekolah Baru. Anehnya, buku Panduan Penyelenggaraan Rintisan Sekolah Bertaraf Internasional (SBI) yang dikeluarkan sebenarnya lebih mengacu pada Model (1) padahal yang dikembangkan saat ini semua adalah Model (2). 
Jelas bahwa sekolah yang ada tidak akan mungkin bisa memenuhi kriteria untuk menjadi sekolah SBI karena acuan yang dikeluarkan sebenarnya ditujukan bagi pendirian sekolah baru atau Model (1). Sebagai contoh, jika sekolah yang ada sekarang ini diminta untuk memiliki guru berkategori hard science seperti Matematika, Fisika, Kimia, Biologi (dan nantinya diharapkan kategori soft science-nya juga menyusul) menggunakan bahasa Inggris sebagai bahasa pengantar, atau memiliki tanah dengan luas minimal $15.000 \mathrm{~m}$, dll persyaratan seperti dalam buku Panduan, maka jelas itu tidak akan mungkin dapat dipenuhi oleh sekolah yang ada.

Sebagai ilustrasi, guru bahasa Inggris di sekolah-sekolah 'favorit' kita saja hanya sedikit yang memiliki TOEFL > 500, apalagi jika itu dipersyaratkan bagi guru-guru mata pelajaran hard science. Ini berarti Dikdasmen tidak mampu untuk menerjemahkan model yang ditetapkannya sendiri sehingga membuat Dikdasmen berresiko gagal total dalam mencapai tujuannya.

Ketiga, konsep ini berangkat dari asumsi yang kurang tepat tentang penguasaan bhs Inggris sebagai bahasa pengantar dan hubungannya dengan nilai TOEFL. Penggagas mengasumsikan bahwa untuk dapat mengajar hard science dalam pengantar bahasa Inggris maka guru harus memiliki TOEFL $>$ 500. Padahal tidak ada hubungan antara nilai TOEFL dengan kemampuan mengajar hard science dalam bhs Inggris. Skor TOEFL yang tinggi belum menjamin kefasihan dan kemampuan orang dalam menyampaikan gagasan dalam bahasa Inggris. Banyak orang yang memiliki nilai TOEFL $<500$ yang lebih fasih berbahasa Inggris dibandingkan orang yang memiliki nilai TOEFL $>500$. Singkatnya, menjadikan nilai TOEFL sebagai patokan keberhasilan pengajaran hard science bertaraf internasional adalah asumsi yang keliru. TOEFL lebih cenderung mengukur kompetensi seseorang, padahal yang dibutuhkan guru sekolah bilingual adalah performance-nya, dan performance ini banyak dipengaruhi faktor-faktor non-linguistic. TOEFL bukanlah ukuran kompetensi pedagogic.

Keempat, tidak semua orang bisa 'dijadikan' fasih berbahasa Inggris (apalagi mengajar dengan menggunakan bahasa Inggris). Sebagai ilustrasi, masih banyak guru kita di pelbagai daerah yang belum mampu menggunakan bahasa Indonesia dengan fasih dalam mengajar! Sebagian dari guru kita di tanah air ini masih menggunakan bahasa daerahnya dalam mengajar meski tinggal dan hidup di lingkungan yang 
menggunakan bahasa Indonesia sebagai bahasa pengantar. Hal ini menunjukkan bahwa adalah tidak mungkin 'menyulap' para guru hard science agar dapat fasih berbahasa Inggris (apalagi memperoleh nilai TOEFL $>500$ seperti persyaratan dalam buku Panduan Penyelenggaran Rintisan SBI tersebut) meski mereka dikursuskan di sekolah bahasa Inggris terbaik.

Kelima, dengan penekanan pada penggunaan bahasa Inggris sebagai medium of instruction di kelas oleh guru-guru yang baik kemampuan penguasaan materi, pedagogi, apalagi masih struggling in English jelas akan membuat proses KBM menjadi kacau balau. Program ini jelas merupakan eksperimen yang berresiko tinggi yang belum pernah diteliti dan dikaji secara mendalam dampaknya tapi sudah dilakukan di ratusan sekolah yang sebetulnya merupakan sekolah-sekolah berstandar " $A$ ". Ratusan sekolah-sekolah berstatus Mandiri yang diikutkan program ini berresiko besar untuk mengalami kekacauan dalam proses KBM-nya. Program SBI ini bakal menghancurkan best practices dalam proses KBM yang selama ini telah dimiliki oleh sekolah-sekolah Mandiri yang dianggap telah mencapai standar SNP tersebut.

Keenam, kritik paling mendasar barangkali adalah kesalahan asumsi dari penggagas sekolah ini bahwa Sekolah Bertaraf internasional itu harus diajarkan dalam bhs asing (Inggris khususnya) dengan menggunakan media pendidikan mutakhir dan canggih seperti laptop, LCD, dan VCD . Padahal negara-negara maju seperti Jepang, Perancis, Finlandia, Jerman, Korea, Italia, dll. tidak perlu menggunakan bahasa Inggris sebagai bahasa pengantar jika ingin menjadikan sekolah mereka bertaraf internasional. Sekolah kita pun sebenarnya tidak perlu harus mengajarkan materi hard science dalam bhs Inggris supaya dapat dianggap bertaraf internasional. Kurikulumnyalah yang harus bertaraf internasional atau dalam kata lain tidak di bawah kualitas kurikulum negara lain yang sudah maju. Jadi, fokus kita adalah pada penguatan kurikulumnya. Penguatan kemampuan berbahasa Inggris bertaraf internasional bisa dilakukan secara simultan dengan memberi pelatihan terus menerus kepada guru-guru bahasa Inggris yang mempunyai beban untuk meningkatkan kompetensi siswa dalam berbahasa Inggris. Selama ini siswa-siswa kita yang melanjutkan pendidikannya di luar negeri tidak pernah diminta untuk mempunyai persyaratan berstandar Cambridge, umpamanya. Jika mereka memiliki tingkat penguasaan yang tinggi dalam bidang studi dan mereka mampu 
memiliki kompetensi berbahasa Inggris yang baik maka mereka selalu bisa masuk ke PT di luar negeri. Bukankah selama ini mereka tidak pernah ditest masuk dengan menggunakan materi Matematika, Fisika, kimia, Biologi, dan lain sebagainya dalam bahasa Inggris? Lantas mengapa mereka harus dilatih sejak awal untuk memahami materi bidang studi tersebut dalam bahasa Inggris (oleh guru yang tidak memiliki kompetensi memadai untuk itu)? Cara yang lebih mudah sebenarnya adalah mengadopsi GCSE sebagai ujian bagi siswa yang berkeinginan untuk melanjutkan pendidikannya ke luar negeri tanpa harus mengorbankan begitu banyak sistem yang telah berlaku. Penekanan pada penggunaan piranti media pendidikan mutakhir dan canggih seperti laptop, LCD, dan VCD juga menyesatkan seolah tanpa itu maka sebuah sekolah tidak bisa bertaraf internasional. Sebagian besar sekolah hebat di Amerika masih menggunakan kapur dan tidak mensyaratkan media pendidikan mutakhir dan canggih seperti laptop, LCD, dan VCD sebagai prasyarat kualitas pendidikan mereka. Program ini nampaknya lebih mementingkan alat ketimbang proses. Padahal pendidikan adalah lebih ke masalah proses ketimbang alat.

Ketujuh, kesalahan mendasar lain adalah asumsi dan anggapan bahwa Sekolah Bertaraf Internasional hanyalah bagi siswa yang memiliki standar kecerdasan tertentu. Kurikulum yang bertaraf internasional dianggap tidak bisa diterapkan pada siswa yang memiliki tingkat kecerdasan rata-rata. Ini juga mengasumsikan bahwa SNP (Standar Nasional Pendidikan) hanyalah bagi mereka yang memiliki tingkat kecerdasan 'rata-rata'. Ini adalah asumsi yang berbahaya dan secara tidak sadar telah 'mengkhianati' SNP itu sendiri karena menganggapnya sebagai 'tidak layak' bagi siswa-siswa cerdas Indonesia. Lantas untuk apa Standar Nasional Pendidikan jika dianggap belum mampu untuk memberikan kualitas yang setara dengan standar internasional? Ini juga paham yang diskriminatif dan eksklusif dalam pendidikan dan menganggap kecerdasan intelektual yang menonjol merupakan segala-galanya sehingga perlu mendapat perhatian dan fasilitas lebih daripada siswa yang tidak memilikinya.

\section{E. Kesimpulan}

Dari kajian di atas dapat disimpulkan bahwa kebijakan Sekolah Bertaraf Internasional (SBI) merupakan upaya pemerintah untuk 
memperbaiki kualitas pendidikan Indonesia agar mempunyai daya saing dengan negara maju di era global. Salah satunya dengan mengadopsi standar internasional anggota OECD sebagai faktor kunci tambahan di samping Standar Nasional Pendidikan.

Dalam perjalanannya, kebijakan SBI mulai terlihat beberapa kelemahan, baik secara konseptual maupun sistem pembelajarannya. Ibarat kata pepatah tiada gading tak retak, maka pemerintah sebaiknya melakukan pelbagai langkah perbaikan konsep dengan melibatkan pelbagai unsur/stakeholders pendidikan dan melakukan studi/penelitian mendalam sebelum kebijakan tersebut bergulir.

\section{F. Saran dan Rekomendasi}

Mengingat betapa banyaknya kelemahan yang ada dari program prestisius ini dan besarnya resiko gagal yang dihadapinya, sudah selayaknya Depdiknas mengevaluasi diri dengan lebih membuka diri terhadap masukan dari masyarakat. Lebih baik mundur satu langkah ketimbang harus mengalami kegagalan total yang sudah nampak di depan mata tersebut. Mungkin formulasi kebijakan di Depdiknas (dalam hal seperti SBI ini) perlu melalui proses konsultasi pada publik atau stakeholders berkali-kali dan studi yang lebih mendalam dengan melibatkan lebih banyak publik, dan tidak sekedar memenuhi syarat minimal birokrasi. Perlu diingat bahwa masyarakatlah yang membiayai dan yang akan menjadi end-user dari produk ini.

Lantas bagaimana dengan UU Sisdiknas pasal 50 ayat (3) yang telah 'terlanjur' dipersepsikan harus mengadopsi kurikulum Cambridge tersebut? Ada dua alternatif untuk itu. Pertama, pasal tersebut perlu diamandemen dan disesuaikan bunyinya agar tidak menimbulkan persepsi yang keliru, atau, kedua, merumuskan kembali apa yang disebut dengan 'satuan pendidikan bertaraf internasional' tersebut. Apa yang telah dilakukan oleh Depdiknas dengan program SBI ini harus dihentikan dan dirumuskan ulang. Jika tidak maka arah pendidikan nasonal kita akan semakin melenceng dari tujuan dan amanah bangsa dan negara kita

\section{G. Daftar Pustaka}

Anonim, 2006. Undang-undang RI Nomor 20 Tahun 2003 tentang Sistem Pendidikan Nasional. WIPRESS 
Anonim, 2006. Rencana Startegis Departemen Pendidikan Nasional Tahun 20052009. Departemen Pendidikan Nasional. Jakarta.

Bush, Tony \& Coleman, Merianne. 2006. Manajemen Strategis Kepemimpinan Pendidikan.(terj.) oleh Fahrurozi. Yogyakarta: IRCiSoD.

Djohar. 2006. Pengembangan Pendidikan Nasional Menyongsong Masa Depan. Yogyakarta: CV. Grafika Indah.

Haryana, Kir. 2007. Konsep Sekolah Bertaraf Internasional (artikel). Jakarta: Direktorat Pembinaan Sekolah Menengah Pertama.

Tilaar. 2001. Manajemen Pendidikan Nasional: Kajian Pendidikan Masa Depan. Bandung: Remaja Rosdakarya,

Usman, Husaini. 2006. Manajemen Teori, Praktik, dan Riset Pendidikan. Jakarta: PT Bumi Aksara., hal 59

http/www.satriadharma.wordpress.com

http/www.64.203.71.11.com 